\title{
Analysis of the risks generated by the tailings ponds near the city of Borșa
}

\author{
Adina Bud $^{1 *}$ \\ ${ }^{1}$ University of Petroșani, University Street no. 20, Romania
}

\begin{abstract}
The paper presents the risks regarding the physical and chemical stability of the tailings ponds grouped under the name of Ds (D1, D2, D3, D4) located on the right bank of the river Cisla near the residential area of Baia Borșa and Colbu tailings pond upstream of the residential area of Borşa. The closure of these tailings ponds was done in a defective manner, without complying with the design and execution rules provided in the Technical Regulation on waste storage. The are two types of risks: first type, due to chemical instability that produces continuous acid drainage and the second type, regarding physical instability, due to erosion and extreme weather conditions which could lead to failure of the dams, with very serious consequences, causing material damages and loss of life. The risk of breaking the dams is even higher as it is located in the vicinity or upstream of residential areas located in a geographical structure of valley type containing the river Cisla with high debit.
\end{abstract}

\section{Introduction}

Maramureș mining has a major impact on the environment through the way the mine's closure was carried out, both locally and in remote areas, having effects even on neighboring countries [1]. In the case of the mining perimeters in the Borsa area, the contaminated mine waters reach the Cisla and Vaser rivers, tributaries of the Viseu River, which flows into the Tisza River, located on the border with Ukraine (non-EU state).

The peculiarity of the Borsa area is given by the fact that at present it is a region without industrial or other development, but with tourist potential. The development of tourism in a polluted area is endangered, given the sensitivity of tourists to heavy metal pollution, the risk of instability of tailings ponds (which have caused many material and human loss of life, including tourist areas, over time), silicogenic dust entrained from tailings ponds. One such example is the one near Stava, a mountain resort in northern Italy on July 19, 1985 at a fluorite mine, killing 268 people, including more than 100 tourists [2] .

Waters contaminated with heavy metals transported by the Viseu River to the Tisza River can trigger legal conflicts with neighboring Ukraine. Romania's relations with both Ukraine and Hungary are sensitive from many points of view, and lately there have been numerous problems with environmental impact due to the transport of household waste on the Tisza River (especially during floods). An accident at Novat Pond in 2000 generated a conflict in relations with Ukraine through heavy metal pollution.

* Corresponding author: bud.adina91@yahoo.com 
In this context, we considered the Borsa area very sensitive for its economic development with the risk of endangering future tourism projects, but also due to the fact that it is on the border with a non-EU state where pollutants are transported.

There were two accidents in Maramureș at the tailings ponds.

The first in January 2000 at the Aurul pond that triggered the cyanide hysteria and the negative reaction to cyanide mining, and the second one, followed in a fatal way, by the breakage of the dam at Novăț pond at a distance of only 3 months. They have caused worldwide concern about the safety of these constructions and a negative impact on mining activity [3].

The first accident provoked the Hungarian state, and the second accident, the Ukrainian state, accusing Romania in all ways of serious negligence.

Currently, these risks are: failure of dams due to physical instability of tailings ponds and entrainment of toxic material and constant pollution by release of heavy metals from mine waters in rivers in Romania and neighboring countries.

\section{Sensitivity of a tourist area to polluted environments}

The analysis of accidents in the world found that tourism was severely affected. An eloquent case is that of the Gold company accident produced in Baia Mare by breaking the dam at the tailings pond and entraining toxic material with heavy metals and cyanide. The cyanide from the Săsar river reached the Lăpuș river, later Someș, Tisa and the Danube. The passage of the cyanide wave in Hungary and the death of fish (due to a different cause - the use of hypochlorite) was amplified by the authorities, the press, and the NGOs, and led to a decrease in tourism in Hungary in the following years [5]. Also, when various media publish that a certain area is polluted with toxic substances such as heavy metals, promotion of tourism suffer, because there are suspicions of contamination of water in the area and consequently of the food used in the local kitchen.

Polluted air is also an impediment to the development of tourism, especially if there are sclerosing dust particles due to the tailings ponds that have not been greened. The wind entails crystalline silica particles (silicogenic dust) as is the case of the Baia Mare area, where the ponds are exposed to this phenomenon. In the Baia Borşa area, the ponds called D1, D1 and D3 are in the immediate vicinity of the residential area and of the pensions with visible erosions and with risk of dust entrainment.

The closure of mining in the historical Maramureş area had a strong social and economic impact through the loss of jobs, which generated the massive migration of the population to other countries, especially from the Borșa - Vişeu area (a region with a long mining history).

In the period following the closure of mining, the remaining population focused on the massive exploitation of wood, generating another environmental impact with amplification of that of mining - the complete cutting of forests on the slopes upstream of ponds - the case of Colbu pond. The Toroioaga massif was completely deforested, later the remaining dry vegetation was burned, creating the premises for an accident by breaking the dam at Colbu pond, at the base of this slope (in case there will be a special meteorological phenomenon).

In recent years, various controls and programs (creation of protected areas and nature reserves) have been developed to reduce deforestation. As a result, the inhabitants of the area and the authorities started to develop programs to promote tourism in the area. 


\section{Description of the Borșa area}

The Borşa area was famous for its natural resources: minerals (complex ores), drinking mineral waters, sulphurous and salty waters, forests, spectacular scenery and for its specific cultural traditions, etc.

The closure of mining led to the sudden cessation of the most important economic activity and the bankruptcy of the largest employer, causing a social shock. The economic perspective of the Borsa area is based on the development of tourism by capitalizing on the remaining potential of the zone. This potential is jeopardized by the way in which the mining activity was closed. A district of Borșa is called Băile Borșa, a famous spa resort, which is currently completely compromised. On the Cisla River, where there is a spa potential (currently unused) there are a large number of unrehabilitated tailings dumps and Colbu Pond- rehabilitated with major deficiencies. The tourist and spa potential used a few decades ago is currently unused. From a social point of view, the Borsa area became infamous through a series of illegal activities, where the state is not able to impose the rule of law.

Mineral resources have been highlighted through prospecting, exploration and exploitation, especially copper (which is currently a major economic stake), but which for the most part have remained unexploited. The copper deposit from the Gura Băii mine was exploited to a small extent, opened and prepared on several horizons, without being exploited. Taking in account the global economic context and the forecasts for the need for copper, gold, silver and other metals, the deposits in the area will undoubtedly become exploitable, reviving the mining activity, but on different bases.

\section{Analysis of the situation of the perimeters in the Borșa area}

The mining perimeters in the Borsa area, with significant environmental impact, are the tailings ponds, tailings dumps and underground mining works. All these structures were considered rehabilitated, but in reality inappropriate works were carried out which currently present a major risk to the environment and to the people who are at risk to lose their lives (especially for ponds D1, D1, D3 and Colbu). Each of these ponds presents major risks, with peculiarities related to the location.

\subsection{Condition of tailings ponds D1, D2 and D3}

Ponds D1, D2 and D3 are located on the right bank of the river Cisla, in the vicinity of residential areas and present risks of physical and chemical stability (Figures $1-3$ ). They have been rehabilitated, but with many deficiencies: without slope correction and without waterproofing, they have ravines through which material is entrained in the river, and geogrids are mostly revealed by entrainment of deposited material (consisting in many areas of sawdust and pieces of wood). 


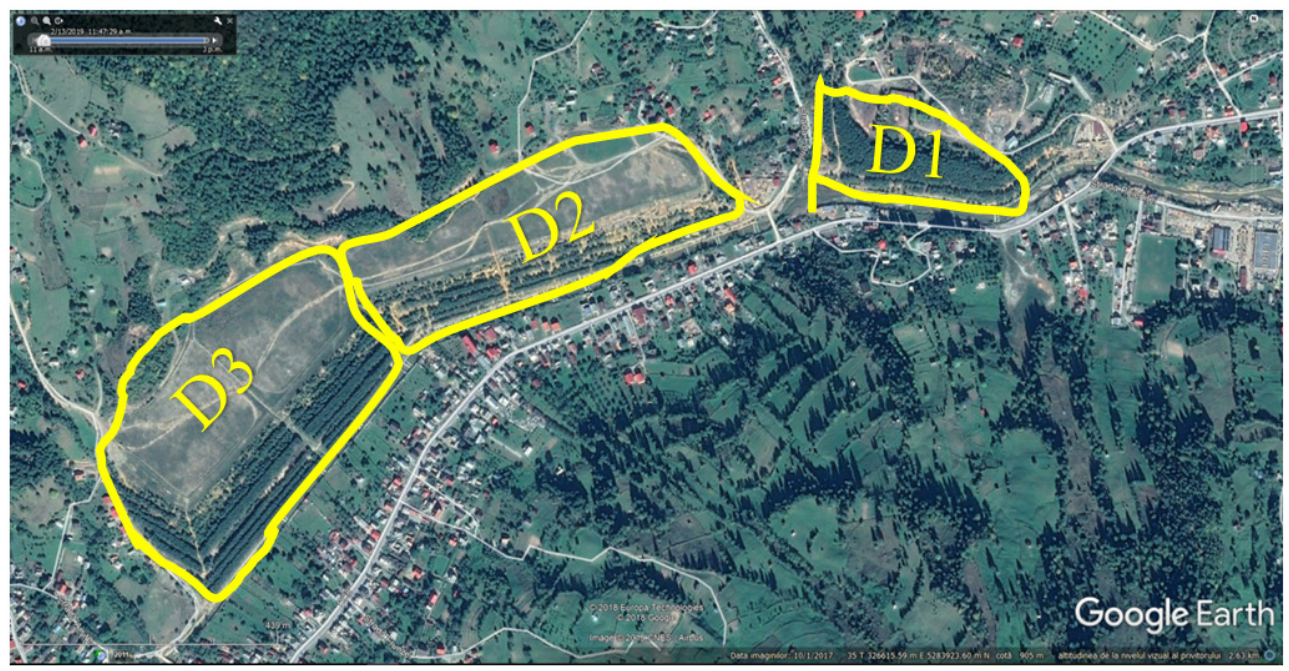

Fig 1. Position of ponds D (1) relative to the Cisla River, Community (Borşa Bai) and road.

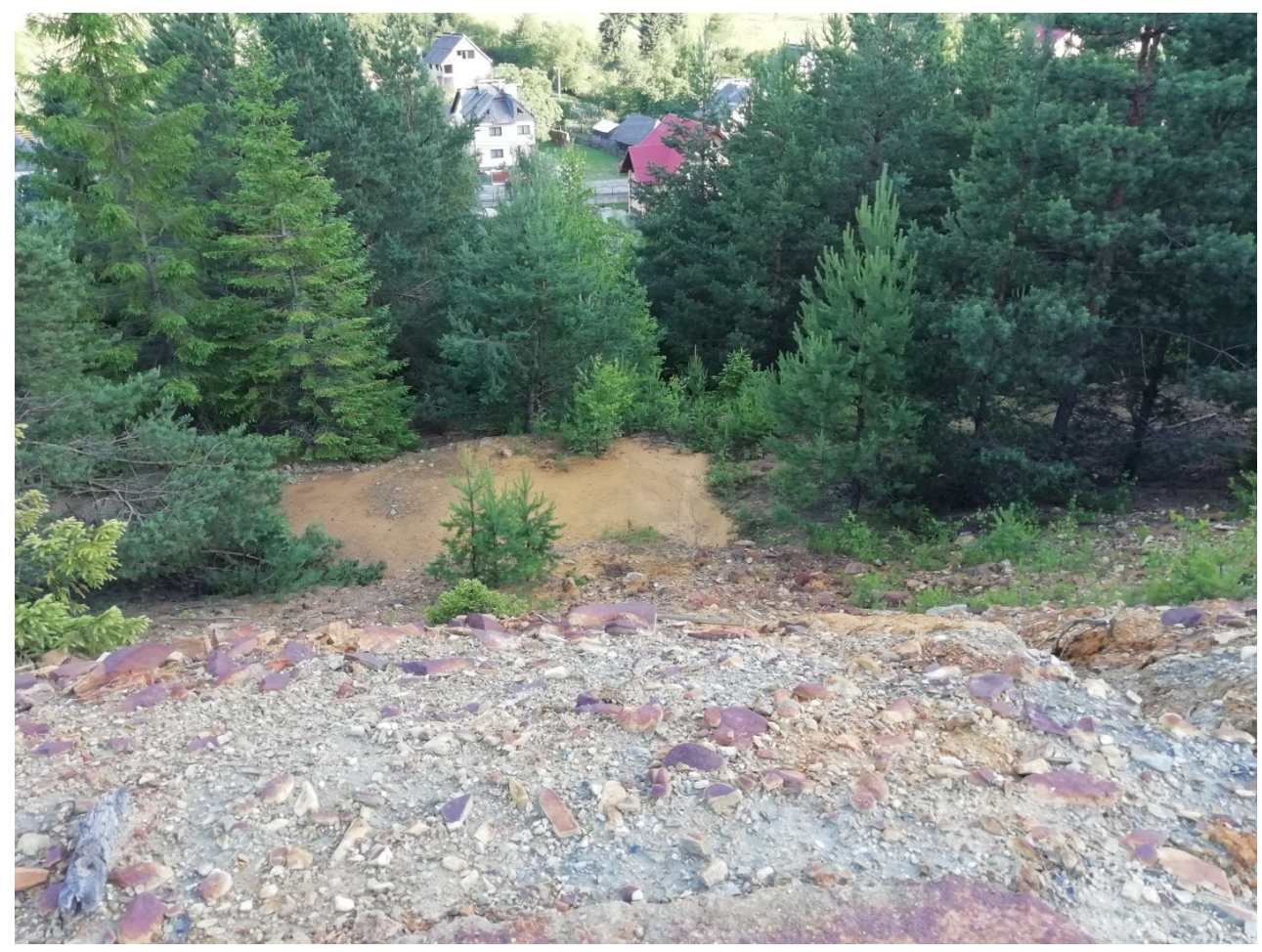

Fig. 2. The condition of the slope of pond D and the proximity to the living areas (sursa foto: A. Bud, 2020). 


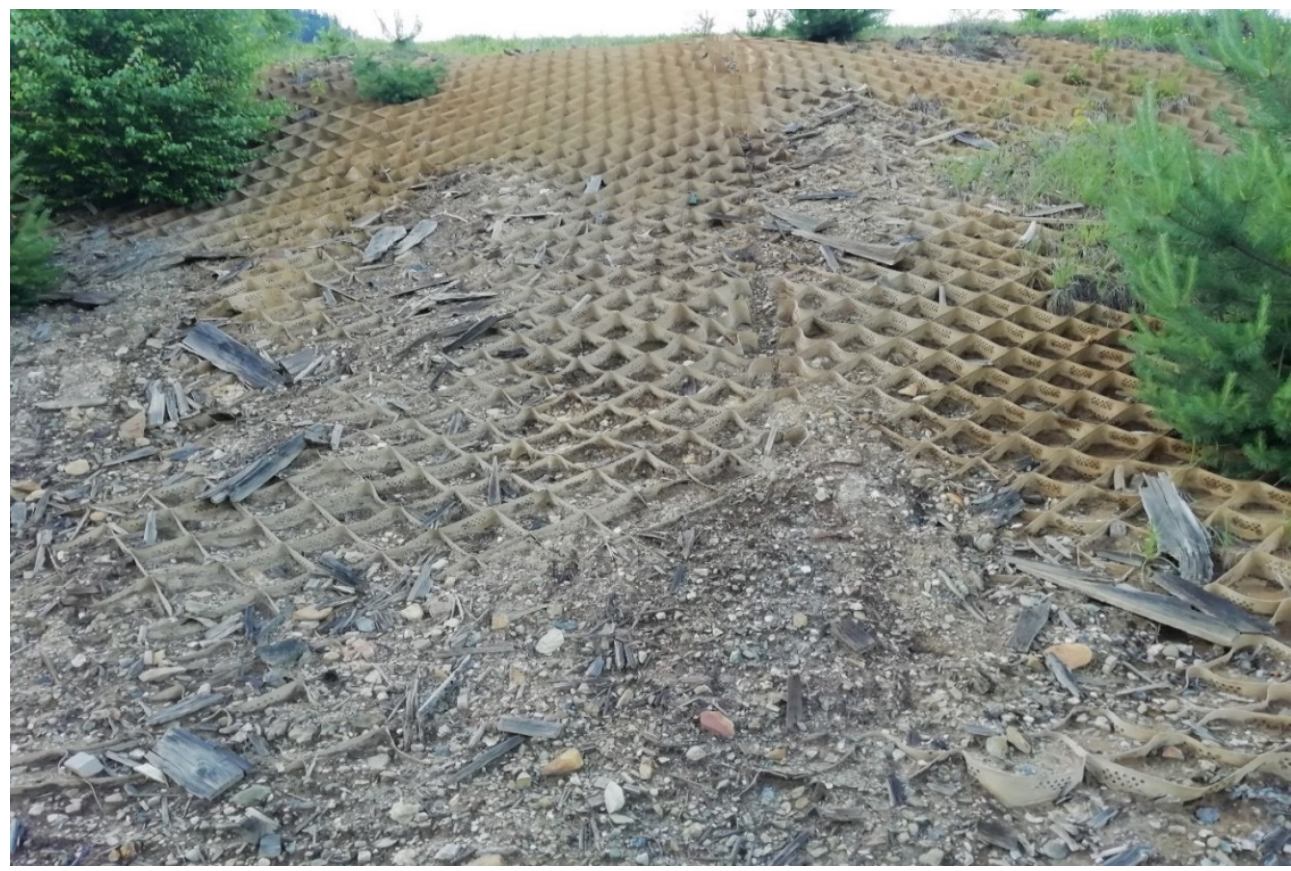

Fig.3. The condition of the slope on ponds D1, D2, D3 (sursa foto: A. Bud, 2020).

The vegetation on the slopes is made up of well-developed fir trees, which apparently give the idea of stability, but this state contributes to the increase of physical instability in the lower part of the roots (the slope is made of fine, granular material).

Pond D1 was put into operation from 1956 to 1970. It is a coastal pond on the right side of the valley of the river Cisla upstream of the confluence with the brook Valea Fătului. The surface at the top level is 7 ha, and at the level of the priming dam is 2.2 ha. The elevation is to altitude of $764.69 \mathrm{~m}$ with dam height of $51.72 \mathrm{~m}$. The amount of tailings is 2.85 million tons. The slope angle is $28^{\circ}$ (the Technical Norm [5] provides for a maximum of $18^{\circ}$ ).

Pond D2 is located on the right slope of the Cisla river valley downstream of the confluence with Valea Fătului. It is a coastal pond and operated between 1972 and 1995. The area at the top level is 7.78 ha, with a tailings amount of 6.68 million tons. The maximum height is $27.67 \mathrm{~m}$, with a slope angle of $26^{\circ}$. Pond D3 is also on the right slope of the river Cisla, downstream of the confluence of the brook Valea Fătului. It is a coastal pond operated between 1980 and 1995, with an area of 6.61 ha at the top level, a capacity of 3.97 million tons and dam height of $32 \mathrm{~m}$ with the slope angle of $24^{\circ}$.

\subsection{State of Colbu ponds}

Colbu ponds (1 and 2) are rehabilitated with completely compromised slopes - almost complete unveiling of geogrids, without vegetation, and at the base, acid water leaks (Figures $4-6$ ). An aggravating fact, which increases the level of risk, is given by the cutting of the forest on the slopes, both in the area of the ponds and upstream. In the emissary, at the base of the pond, there is still a sterile flotation today - which had to be relocated and stored on the pond, later waterproofed the same time with the whole pond.

Colbu Pond 1 is located on the valley of the Colbu brook at $300 \mathrm{~m}$ upstream of the confluence with the river Cisla, being a valley pond put into operation in 1985, with a 
capacity of about 3 million tons, an area of 5.1 ha at the level of the canopy, the height of $45 \mathrm{~m}$ and the slope angle of $25^{\circ}$.

Colbu Pond 2 is upstream of Colbu Pond 1, put into operation in 1989, has a capacity of 900 thousand tons and an area of 2.25 ha at the canopy. The slope angle is $28^{\circ}$.

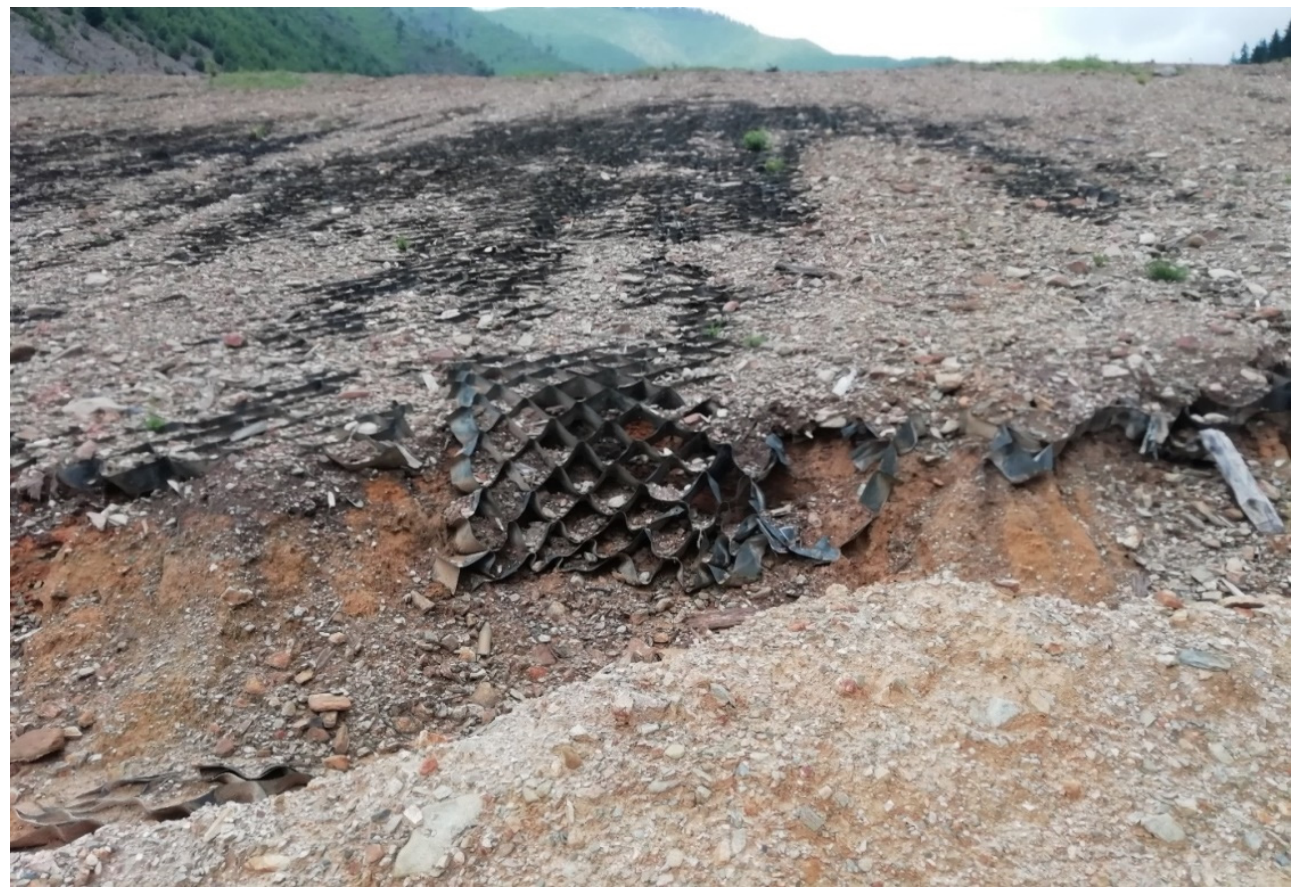

Fig. 4. The condition of the Colbu tailing pond - external slope (sursa foto: A. Bud, 2020).

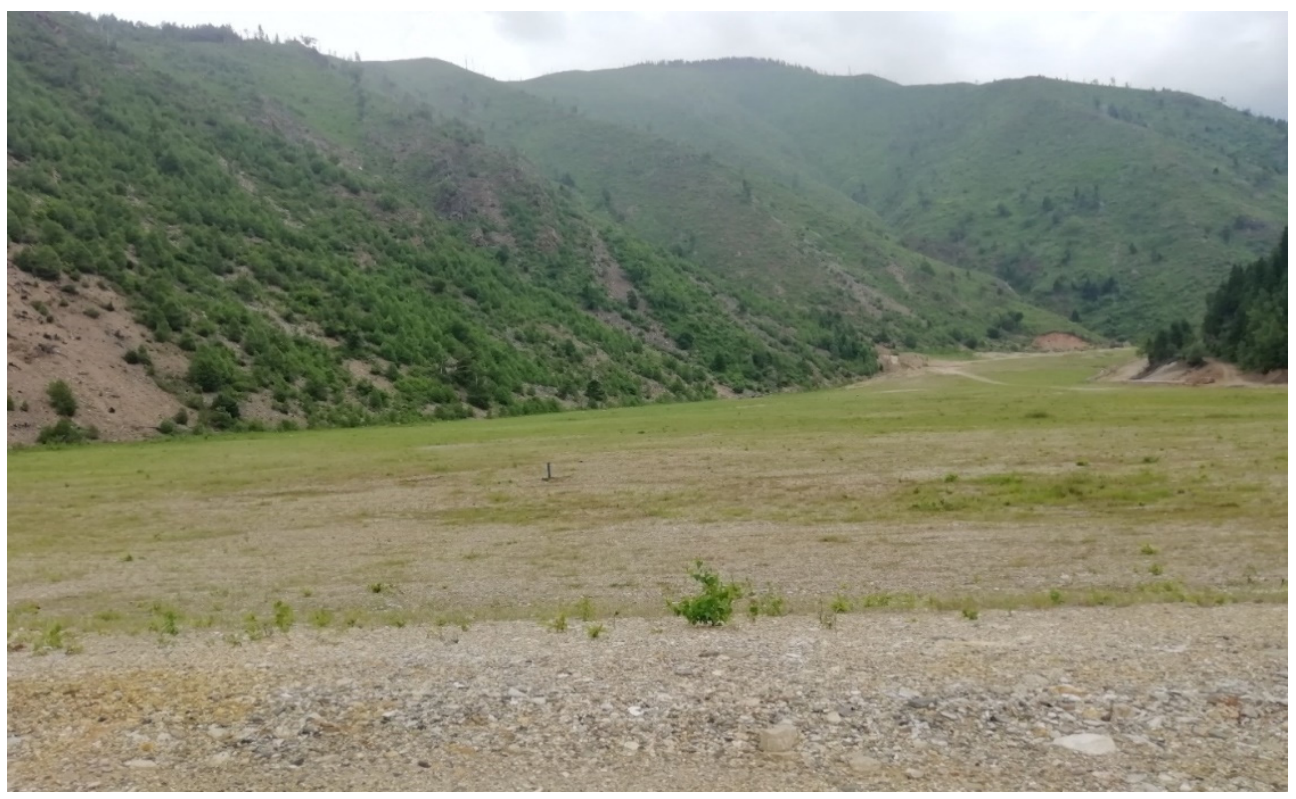

Fig. 5. Colbu pond- internal slope and versantul din amonte defrisat (photo A. Bud, 2020). 


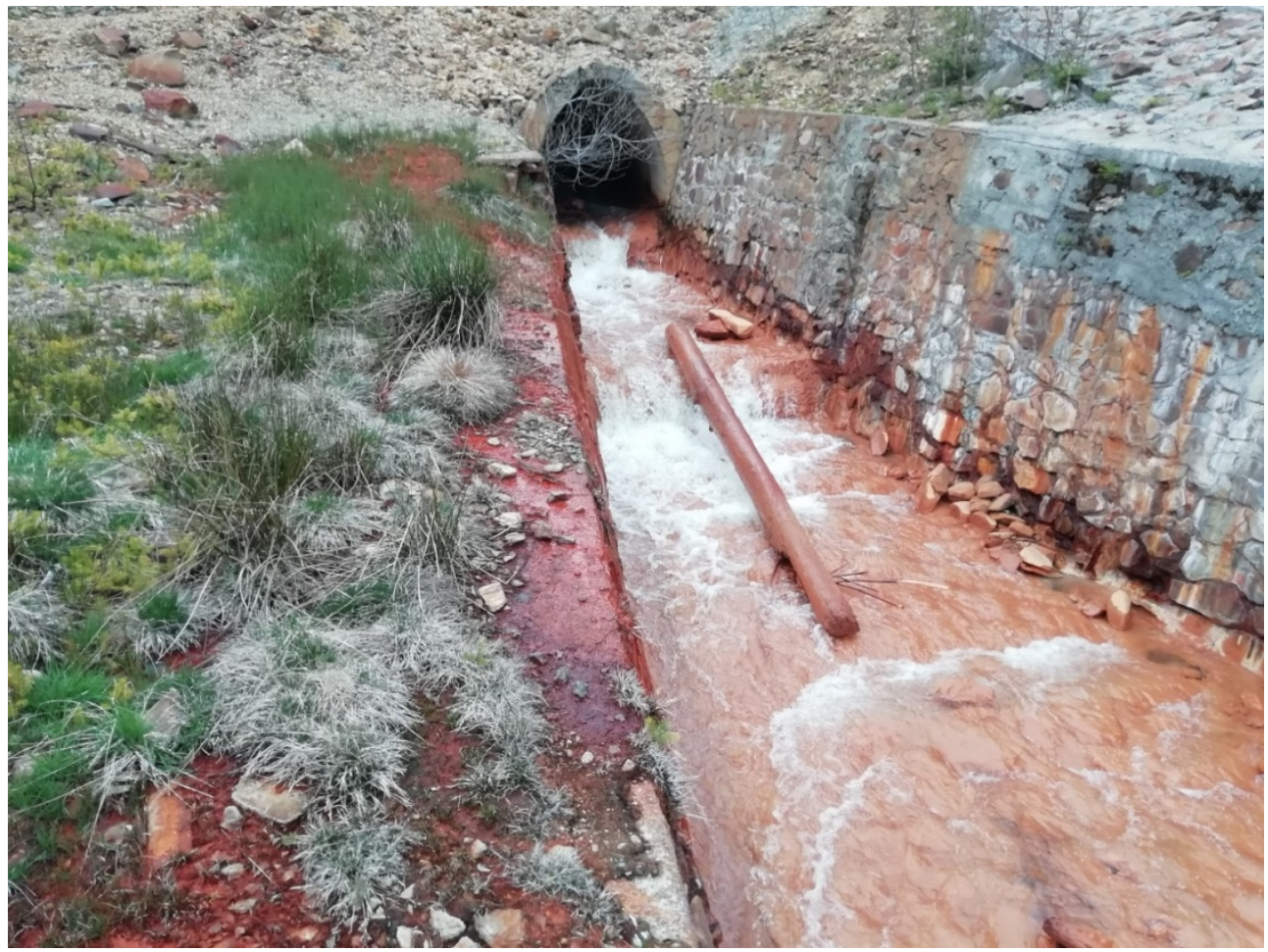

Fig. 6. Acid leaks at the base of Colbu tailing pond (sursa foto: A. Bud, 2020).

The previous photos show the advanced stage of degradation of the slope rehabilitation works, the deforestation upstream and the level of reactivity of the pond through the drainage of acid waters with heavy metals at its base. Also, the acid drainage irreversibly compromises the works made of concrete with Portland cement. Photo 5 shows the leaks through the dam and the detachment of the concrete stones from its base.

\section{Conclusions}

These tailings ponds pose a particular risk to the population in the area and compromise the development of tourism in the region.

The Borșa area is located in a special natural setting with high potential for tourism due to geographical conditions -mountains, nature reserves, protected areas, history and natural resources -mineral waters, salt water, sulfurous water. The local and regional administration develops numerous projects for tourism, but ignores the risks involved in the stability of tailings ponds and the entire mining perimeter.

A major accident at Colbu pond, due to the conditions described in the work (faulty rehabilitation of the slope, deforestation upstream) with discharge into a high debit river (Cisla) having a relatively narrow valley, coupled with the instability of D ponds, would cause numerous damage and loss of life. Also, ponds D, by failure of the dams, could lead to the above mentioned disaters. A constant pollution is given by acid drainage and the entrainment of fine material, depending on the meteorological conditions (runoff, ravines creation, wind entrainment). If sustainable development of the region is desired, immediate action is needed. 


\section{References}

1. I. Bud, S. Duma, D. Gușat, I. Paşca: The environmental impact of the exploitation of non-ferrous ores in the mining region Baia Mare (Risoprint Publishing House, Cluj-Napoca, 2019)

2. F. Luino, De Graff, Natural Hazards and Earth System Sciences. Copernicus Publications 12, 1030-1042 (2012)

3. I. Bud, S. Duma, I. Denuț, O. Benciu, D. Pintea, Accidents at tailings ponds (Risoprint Publishing House, Cluj-Napoca, 2005)

4. I. Bud, S. Duma, I. Smical, V. Oros, Mining Revue, 20 (1), (2014)

5. Order no. 757 (2004), for the approval of the Technical Norm regarding the waste storage, Official Gazette, Part I, No. 86/2005 